officers. He was awarded the D.S.M. and Honorary C.M.G., and the Grand Cordon of the Order of the Nile, and was appointed editor-in-chief of the United States Medical History of the War. He was instrumental in founding in Porto Rico an Institute of Tropical Medicine and Hygiene, and in arranging for its expansion into a School under the auspices of the Columbia University, New York. After experience of 4,000 cases of sprue he concluded that the essential factor in its causation was unbalanced diet, and that when to this was added infection by Monilia, of which he recognised only one species, there resulted sprue. He unswervingly advocated and fruitfully practised that combination of clinical observation and scientific investigation which has strikingly advanced tropical medicine.

Clayton Lane.

Thoughts of a Schoolmaster (or Common Sense in Education). By H. S. Shelton. Pp, 256. (London : Hutchinson and Co. (Publishers), Ltd., n.d.) $6 s$. net.

THE strength of this book lies in the rich variety of its author's experience. As a boy he was in four schools, and as a master in twenty-five, including public, grammar, co-educational, private, proprietary and technical schools. Not that by nature he was a 'rolling stone', but that by necessity he was transferred from place to place during the War. $\mathrm{He}_{\theta}$ deals only with secondary schools, and he touches many topics, including the 'unpopularity' of schoolmasters, the tradition of the headmaster, salaries, co-education, discipline and so on; and whether one agrees with him or not, his criticism is always practical and to the point, and it is often constructive.

On the subject of science teaching, Mr. Shelton condemns the general neglect of biology, and suggests, as a practicable reform, advanced courses in biology, with interchange between neighbouring schools, and special attention to biology in country schools. $\mathrm{He}$ pleads also for universal courses in general science, not, however, made up of scraps of chemistry and physics and biology and geology and astronomy merely strung together, but conceived as a single subject with many interrelated divisions. The author is not, and probably does not claim to be, free from the charge of dogmatism. But he writes with knowledge, at a time when our secondary school system is very far indeed from being above criticism.

The Principles and Practice of Surveying. By Prof. C. B. Breed and Prof. G. L. Hosmer. Vol. 2 : Higher Surveying. Fourth edition. Pp. xix +603 . (New York: John Wiley and Sons, Inc.; London : Chapman and Hall, Ltd., 1934.) 21s. 6d. net.

Although this work is an American publication, it deals with its subject in such a way as to be as suitable to students as most of the well-known English books thereon. It is extremely well set out and lucid in style, and includes such modern developments as those of geology in relation to topography, and aerial photography as applied to surveying. A most useful set of problems is appended at the end of each section, but it is unfortunate that the answers to these are not given.

With the increasing use of precise levels, fuller details relating to the parts of such instruments could have been given with advantage, while the reproduction of the photographic illustrations is not up to the standard of the letter-press. It would not be usual in Great Britain to expand the portions relating to the flow of water in channels to so great an extent, these constituting a chapter generally found in large works on hydraulics.

The size and method of binding is evidently designed for field use; in its general tenor, the work can be confidently recommended to students who are preparing for engineering degrees of honours standard, and to all who are interested in the subject.

\section{B. H. K.}

Progress of Archceology. By Stanley Casson. Pp. xii $+111+24$ plates. (London : G. Bell and Sons, Ltd., 1934.) 6s. net.

Mr. Casson surveys progress in archæological discovery during the last fifteen or twenty years throughout the world, dividing it into nine main archæological provinces. His purpose is to touch upon the most significant discoveries or excavations in each and to bring out, where such consideration is appropriate, their interrelation. Mr. Casson's book is pleasantly and easily written and well illustrated; but on even the most generous interpretation of the lines upon which a book of this kind can be written for an educated but non-technical public, it is far too sketchy. The treatment of Africa, even including Egypt, and of America, for example, is quite inadequate, in view of recent work in both continents. The first chapter, on the aims and methods of archæology, is by far the best, though it shows some confusion of thought, and the definition of the field of archrology not only begs the question, but also is contradicted by the pages which immediately follow.

\section{Practical Plant Anatomy : an Elementary Course for} Students. By Comyns J. A. Berkeley. Pp. 112. (London : University of London Press, Ltd., 1934.) $3 s$.

A GOOD practical guide to elementary botany is sorely needed, and this book by Mr. Comyns Berkeley will fill part of the gap ; the practical plant anatomy is dealt with, and this is done extremely well. The author is obviously conversant with the practical side of botanical study, for he not only gives clear directions as to methods of approach but he also gives hints of difficulties-sometimes slight, but irritating - that are constantly cropping up. Another problem that students and even teachers are constantly meeting is that of sources of material. Few books give the reader any idea of where to obtain their type specimen. Mr. Berkeley gives sufficient help in a series of tables. This is very useful.

It is a pity that the author did not go a little further and cover completely an intermediate science course in botany. 